\title{
Archeological Resource Survey of a 2.9-mile Proposed Pipeline Corridor on University Lands in Ward County, Texas
}

Joel Butler

Follow this and additional works at: https://scholarworks.sfasu.edu/ita

Part of the American Material Culture Commons, Archaeological Anthropology Commons, Environmental Studies Commons, Other American Studies Commons, Other Arts and Humanities Commons, Other History of Art, Architecture, and Archaeology Commons, and the United States History Commons

Tell us how this article helped you.

This Article is brought to you for free and open access by the Center for Regional Heritage Research at SFA ScholarWorks. It has been accepted for inclusion in Index of Texas Archaeology: Open Access Gray Literature from the Lone Star State by an authorized editor of SFA ScholarWorks. For more information, please contact cdsscholarworks@sfasu.edu. 


\section{Archeological Resource Survey of a 2.9-mile Proposed Pipeline Corridor on University Lands in Ward County, Texas}

\section{Creative Commons License}

\section{(c) (1) (8)}

This work is licensed under a Creative Commons Attribution-NonCommercial 4.0 International License 


\section{Archeological Resource Survey of a 2.9-mile Proposed Pipeline Corridor on University Lands in Ward County, Texas}

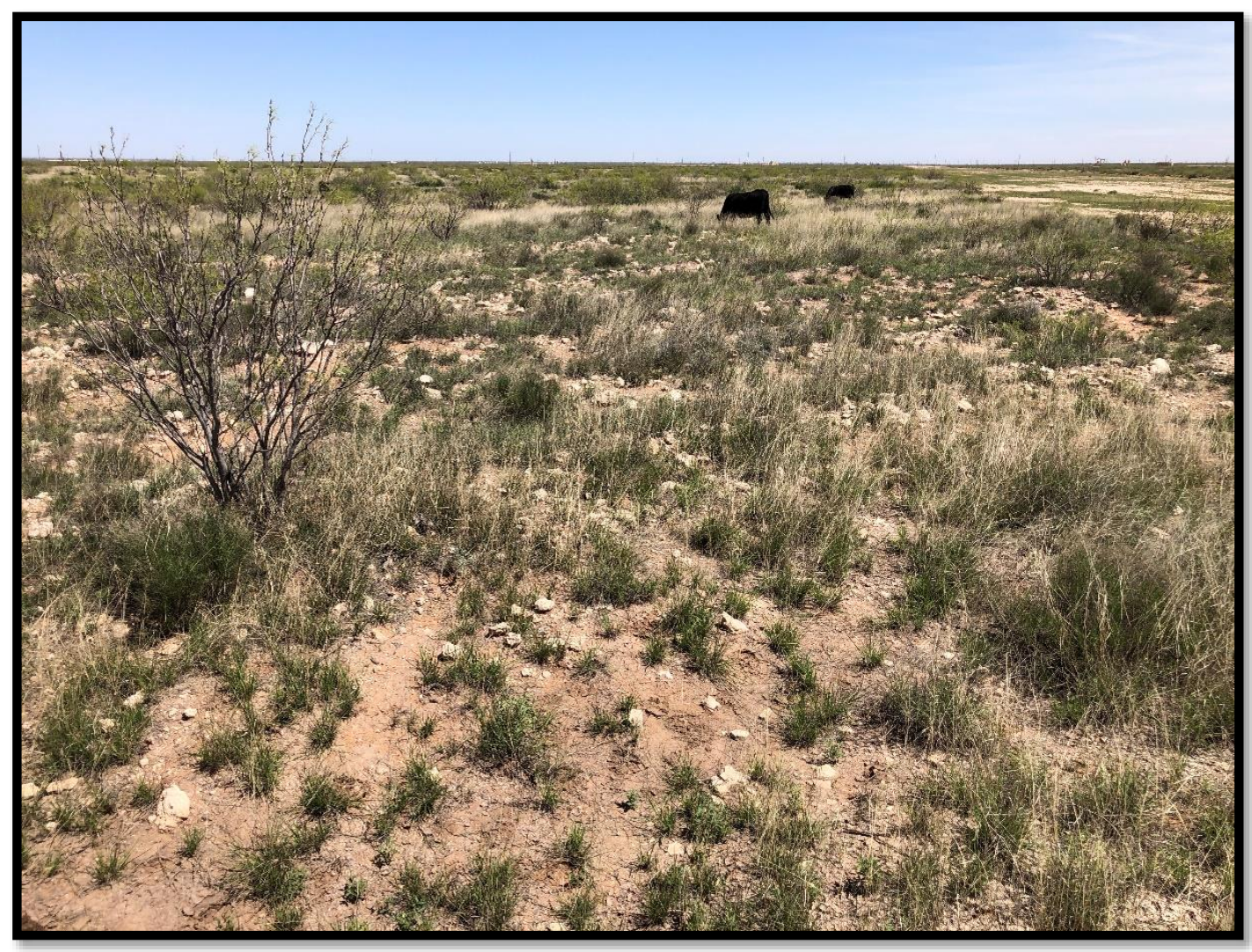

Prepared by Flatrock Engineering and Environmental, LLC

Joel Butler

Principal Investigator

FLATRLCK ENGINEERING AND ENVIRLNMENTAL

May 2020 


\title{
Archeological Resource Survey of a 2.9-mile Proposed Pipeline Corridor on University Lands in Ward County, Texas
}

\author{
By Joel Butler, Principal Investigator for Salt Creek Midstream, LLC.
}

Texas Antiquities Permit Number: 9355

\section{FLATRDCK ENGINEERING AND ENVIRDNMENTAL}

\author{
18615 Tuscany Stone, Suite 200 \\ San Antonio Texas, 78258
}

Flatrock Cultural Resources Technical Report No. 12

Cover Photograph: Typical view of Project Area with surface evidence of chaining, facing north.

(C)2020 by Flatrock Engineering and Environmental, LLC. 


\section{Abstract}

At the request of Salt Creek Midstream (SCM), Flatrock Engineering and Environmental, LLC (Flatrock) conducted an intensive archeological resource survey of approximately 2.9 miles (15,312 feet) of a proposed pipeline corridor on University Lands in northern Ward County, Texas. Because the project will take place on property owned by the University of Texas, a political subdivision of the State of Texas, it is subject to the Antiquities Code of Texas (Texas Natural Resources Code, Title 9, Chapter 191) and its associated regulations (13 TAC 26). The archeological survey was carried out under Antiquities Permit Number 9355.

A pedestrian field survey was conducted by Flatrock archeologist Joel Butler on March 30 and 31, 2020. A corridor 100 feet in width, encompassing 38.7 acres, was surveyed during fieldwork. Surface visibility ranged from 80 to 100 -percent along the 100 -foot survey corridor and revealed predominantly heavily disturbed or deflated surfaces. The entire corridor was 100-percent surface inspected and 31 shovel tests were excavated to locate and/or evaluate the potential for buried cultural deposits; all shovel tests were negative. No artifacts or archeological sites were identified during fieldwork and no historic structures were visible from the right-of-way.

Flatrock recommends that construction of the pipeline be allowed to proceed as planned, with no further archeological investigations. However, it is recommended that if any cultural resources are encountered during construction, the Texas Historical Commission and University Lands should be notified, and a qualified archeologist should evaluate the findings.

No artifacts were collected or curated during this project; field records will be curated at the Center for Archaeological Studies (CAS) at Texas State University, San Marcos. 


\section{Table of Contents}

Abstract of Figures

\section{List of Figures}

Figure 1. Project location overlaid on USGS 7.5-minute topographic maps. .........................................

Figure 2. Soils within the Project Area........................................................................................... 4

Figure 3. Previous surveys and documented archeological sites within one kilometer of the Project........ 8

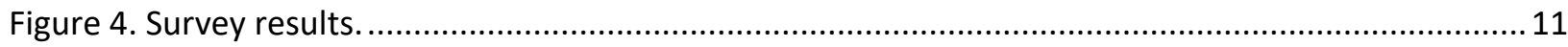

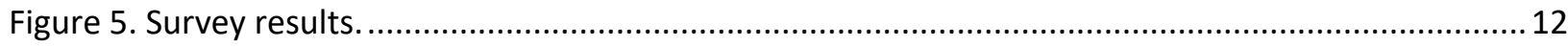

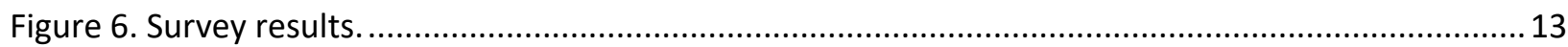

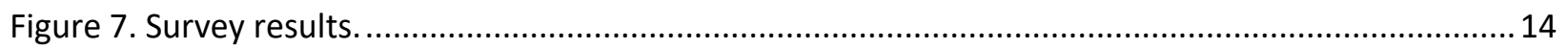

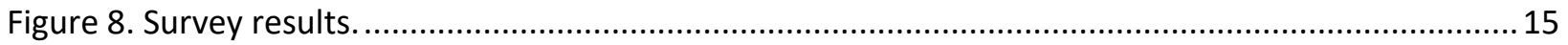

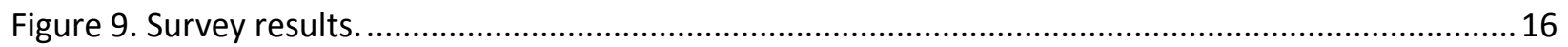

Flatrock Engineering \& Environmental, LLC 
Archeological Resource Survey of the Olifant Pipeline, Ward County, Texas.

Figure 10. View of the Project centerline with existing pipeline ROW on right, facing east....................17

Figure 11. 1954 detailed aerial view of earthworks in the Project Area. ................................................. 18

Figure 12. Ground view of earthworks in the eastern Project Area, note large quantities of caliche on the

surface, facing west.

Figure 13. Intact coppice dunes in western portion of the Project Area, facing northwest.

20 


\section{Chapter 1}

\section{Introduction and Management Summary}

At the request of Salt Creek Midstream (SCM), Flatrock Engineering and Environmental, LLC (Flatrock) conducted an archeological resource survey of a proposed 2.9-mile petroleum pipeline corridor on University Lands in northern Ward County, Texas. The proposed Oliphant pipeline corridor (Project Area) consists of a 2.9-mile (15,355 feet) gas line with a 0.45 -mile (2,397 feet) crude line installed 65 feet to the west and parallel to the gas line at the western end. The depth of disturbance will be six feet throughout the Project. The proposed survey corridor is 100 feet surrounding both lines; therefore, the survey area varies from 100 to 165 feet in width and encompasses 38.7 acres.

Because the property is owned by University Lands, a political subdivision of the state, it is subject to compliance with the Antiquities Code of Texas (Texas Natural Resources Code, Title 9, Chapter 191) and its associated regulations (13 TAC 26). Therefore, Antiquities Permit number 9355 was obtained from the Texas Historical Commission (THC) to carry out field investigation.

The project will involve the installation of the 2.9-mile gas pipeline and parallel 0.45 -mile crude oil pipeline through open-cut trenching. The depth of trenching will average six feet below grade throughout the project. Construction will take place within a 50-foot wide corridor which will be cleared and graded. Therefore, the area of potential effects (APE) for the project measures 50 feet in width along both pipelines to a depth of six feet. This investigation was conducted to identify and avoid or preserve any cultural resources eligible as a State Antiquities Landmark (SAL) within the project's APE.

Joel Butler, serving as Principal Investigator and field director, surveyed the pipeline on March 30 and 31, 2020. Field conditions were fair and windy. The entire Project APE was inspected, and 31 shovel tests were excavated to identify artifacts and evaluate the potential for buried cultural deposits within the Project. All shovel tests were negative, and no archeological sites or isolated finds were identified during field investigations. No artifacts were collected, and all field records will be permanently housed at the Center or Archaeological Studies (CAS) at Texas State University in San Marcos. 
Archeological Resource Survey of the Olifant Pipeline, Ward County, Texas.

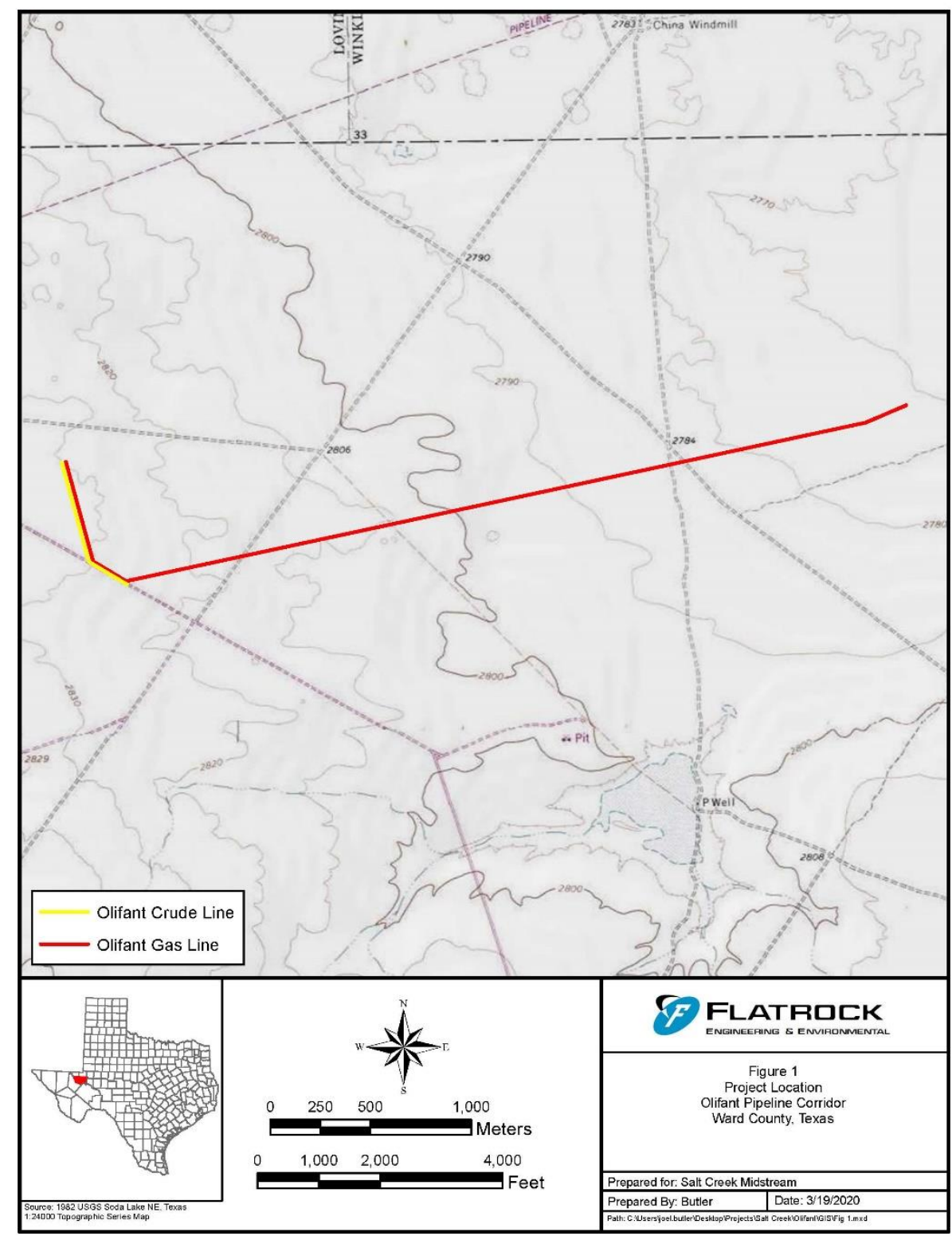

Figure 1. Project location overlaid on USGS 7.5-minute topographic maps.

Flatrock Engineering \& Environmental, LLC 


\section{Chapter 2}

\section{Environmental Background}

\section{Geographic Setting}

The Project Area is located in the Chihuahuan Basins and Playas portion of the Trans-Pecos Chihuahuan Desert EPA ecoregion, an arid region of low rainfall and relatively low elevation (less than 3,500 feet [Omernik and Griffith 2013]). The Project Area itself is in a near-level to gently sloping region of mesquite and creosote brush punctuated by incised arroyos and eroded and pedestaled landforms. Elevations within the Project Area range from 2,775 feet above mean sea level (AMSL) at the eastern terminus to 2,830 feet AMSL at the western terminus.

\section{Geology and Soils}

According to the Geologic Atlas of Texas, the proposed pipeline route is underlain by areas of Holocene windblown sand and Pleistocene evaporites (USGS 2007). Soils within the proposed pipeline corridor are mapped as shallow Delnorte and Sharvana Series and moderately deep to moderately deep Wickett and Pyote Series (USDA-NRCS; 2020). Archeological resources located within these contexts are typically limited to the ground surface or shallowly buried. In addition, archeological sites - particularly prehistoricage sites - are often in fair to poor condition due to erosion and surface disturbances.

\section{Vegetation and Climate}

Arid Chihuahuan Desert vegetation typically includes grassland and shrub-land but can include conifer and hardwood forest flora at high elevations (Omernick and Griffith 2013). Vegetation common to the Chihuahuan Desert include creosote bush, tarbush, fourwing saltbush, blackbrush, gyp grama, alkali scaton, honey mesquite, red berry juniper, prickly pear cactus, ocotillo, stool, and other desert shrubs and cacti (Omernik and Griffith 2013; Stahl and McElvaney 2012). Vegetation observed within the Project Area included honey mesquite, creosote bush, prickly pear, Spanish dagger, broomweed, and various bunch grasses.

The majority of the precipitation in this area occurs in the summer months during brief thunderstorms (Omernik and Griffith 2013; Stahl and McElvaney 2012). The average annual rainfall is 12.3 inches. Temperatures range from an average low of $29.6^{\circ} \mathrm{F}$ in January to an average high of $97^{\circ} \mathrm{F}$ in July (University of Missouri 2020). 


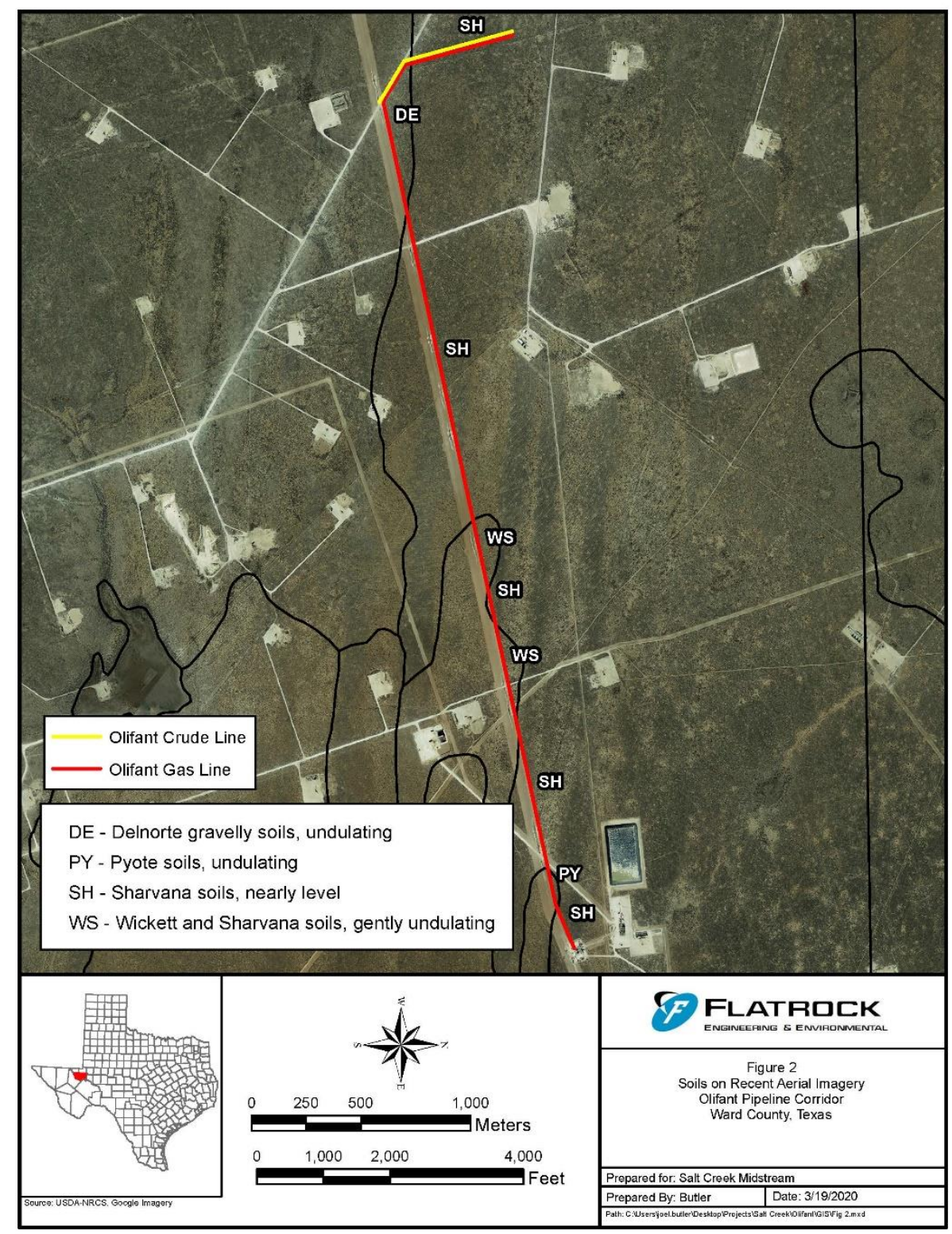

Figure 2. Soils within the Project Area.

Flatrock Engineering \& Environmental, LLC 


\section{Regional Chronology and Cultural Background}

The Project Area is situated within the Trans-Pecos archeological region, characterized by its numerous natural rock shelters formed in limestone canyons and cliffs, as well as its ubiquitous raw lithic outcrops and isolated micro-environments near artesian springs. Offering protection from the elements, rockshelter localities were consistently attractive to hunter-gatherers, and from an archeological standpoint, they create ideal conditions for the preservation of burned rock middens, organic materials, burials, and petroglyphic and pictographic rock art. The region also contains many short term or singleuse campfire hearths of fire-cracked rock. In the right conditions, these hearths may contain a wealth of datable carbon and/or floral and faunal remains, though frequently they are deflated and scattered by the largely erosional desert environment and contain no artifacts other than burned rocks.

Three major intervals or periods are identified in the Prehistoric stage: the Paleoindian, the Archaic, and the Late Prehistoric.

\section{Paleoindian Period}

The arrival of humans in the New World occurred between 16,000 and 14,500 years before present (BP; Gilbert et al. 2008, Pitblado 2011), and until recently, it was generally thought that the Paleoindian Period in Texas did not begin until around 12,000 BP (Perttula 2004). However, new evidence from the Debra Friedkin and Gault sites in Central Texas have begun to push the date of earliest occupation back to around 15,000 BP (Swaminathan 2014; Gault School 2016). Generally, there is a lack of radiocarbon dates from unambiguous Paleoindian contexts in Trans-Pecos. Therefore, the Paleoindian Period in the Trans-Pecos Region is currently estimated to range from 12,000 to 8,000 BP (Miller and Kenmotsu 2004).

As the Pleistocene ended, diagnostic Paleoindian materials in the form of Clovis, Folsom, and Plainview projectile points began to enter the archeological record. These points were lanceolate-shaped and fluted for hafting to wooden spears. Using the launching momentum from atlatls (spear-throwers), large game such as mammoth, mastodons, bison, camel, and horse were frequently taken (Black 1989). In addition to large game, Paleoindian groups also harvested smaller prey including antelope, turtle, frogs, and other small to medium-sized game (Miller and Kenmotsu 2004). Stylistic changes in projectile point technology occurred during this later portion of the period, eventually shifting to Dalton, Scottsbluff, and Golondrina traditions. Environmental studies suggest that Late Pleistocene climates were wetter and cooler (Mauldin and Nickels 2001; Toomey et al. 1993), gradually shifting to drier and warmer conditions during the Early Holocene (Bousman 1998). The end of the Pleistocene was likely arid to semiarid, and prickly pear and agave populations were high (Bousman et al. 1990:94, 98). As megafauna gradually died off and the ranges of other large game changed during the shift to a warmer climate, subsistence patterns shifted toward smaller game and plant foraging. Intact Paleoindian occupations in the Trans-Pecos region are somewhat rare and consist mostly of kill sites found near rockshelters (Turpin 1995), or isolated projectile points within multicomponent scatters (Miller and Kenmotsu 2004).

\section{Archaic Period}

The Archaic Period exhibited a shift from more mobile hunting strategies to a heavier reliance on a broader spectrum of local plants and animals, and broadly dates to 8,000 to 1,800 BP (Miller and Kenmotsu 2004). During the Archaic the construction of pithouses and huts occurred in the western TransPecos Region, and rockshelters were more intensively utilized everywhere, leading to an increase in rock art (Miller and Kenmotsu 2004). The Late Archaic in the Trans-Pecos is the best understood sequence, and 
current data suggest that a population increase took place with a heavier reliance on specialized food processing and the introduction of small-scale agriculture in some locations (Miller and Kenmotsu 2004). Common site types of this period include large burned rock middens, which tend to be exposed on mesa tops overlooking canyons and water sources.

Turpin (1995) has summarized 10 prehistoric periods and phases unique to the Trans-Pecos. Some overlap in projectile point technologies shared between the Trans Pecos and Central Texas. Hester (1995:436438) places the Early Archaic in neighboring Central Texas between 7,950 and 4,450 BP based on Early Corner Notched and Early Basal Notched projectile points. Collins' (1995:383) dating of the Early Archaic period to $8,800-6,000 \mathrm{BP}$ is founded on unstemmed point types. Middle Archaic materials date from about 6,000 to 4,000 BP (Collins 1995:383). The last subperiod of the Archaic falls between 4,000 and 800 BP (Collins 1995:384).

\section{Late Prehistoric Period}

The commonly held date for the beginning of this period is 1,800 BP with the transition to the bow and arrow (Hester 1980). This technology enabled prehistoric hunters to harvest prey from greater distances with a lesser need for brushless, wide open spaces required for atlatl maneuverability. The use of arrows is indicated by smaller-sized, triangular projectile points. Another turning point in the Late Prehistoric period is the first substantial presence of pottery (Miller and Kenmotsu 2004). Trans-Pecos sites dating to the Late Prehistoric suggest a continued reliance on rockshelters, but also show up in the form of tipi rings, cairn burials, and pit houses built along water source terraces (Miller and Kenmotsu 2004). Perdiz arrow points, groundstone implements, beveled bifacial knives, end-notched sinker stones, and ornamental beads add more diversity to the archeological record during this interval.

It is also important to recognize temporal variation in the adoption of certain technologies and practices in the Late Prehistoric Period. Dates in the eastern Trans-Pecos show that the adoption of ceramics, smallscale agriculture, and architectural forms (e.g. pithouses, huts/wickiups) around 1,000 BP was significantly later than their development farther west (Miller and Kenmotsu 2004). Pueblo structures also developed earlier and were more common in the western Trans-Pecos. Ring middens, hearthfields, lithic scatters, and wickiup rings remained the most common site types in the eastern Trans-Pecos (Miller and Kenmotsu 2004).

\section{Land Modifications and Historical Land Use}

The Project Area was generally held property of the State of Texas until it was deeded in perpetuity to the University of Texas. Land use within the survey area has historically, and continues to, consist of cattle ranching and petroleum production. The resulting land modifications have included erosion from overgrazing and extensive deep disturbances from brush removal projects. Currently, regional land use is transitioning to a petroleum-based economy with many pipelines, drill pads, and supporting facilities throughout the upper Trans Pecos and the Permian Basin.

\section{Previous Archeological Investigations}

The Texas Archeological Sites Atlas (Atlas; THC 2020) was consulted to identify previous surveys and recorded cultural resources (Figure 3). According to the Atlas, in 2017, Lone Mountain Archeological Services conducted a large, gridded seismic survey that encompasses the entire Project Area. 
No previously recorded archeological sites are recorded within or within one kilometer $(\mathrm{km})$ of the Project, but seven sites are located within two km, all but one of which (41WK139) were recommended as eligible for listing in the National Register of Historic Places (NRHP, Figure 3). The Atlas makes no reference as to what these site types are other than 41WK139 (a small lithic scatter), though it is likely that, given the eligible recommendations, the sites mostly consist of open campsites with datable thermal features, retaining charcoal combined with other potential researchable materials (diagnostic artifacts, preserved plant materials, etc).

Although the Project is located within the 2017 survey grid, site 41WR139 was documented within it after the 2017 survey, indicating the potential for missed sites in the area.

\section{Archeological Site Potential}

Prehistoric sites within the Project area were most likely to consist of prehistoric lithic scatters and hearths/burned rock concentrations, likely limited to the surface or very shallowly buried. Historic-age sites were most likely to occur as isolated trash dumps. Based on historic aerial imagery and University of Texas' ownership for over 100 years, no structural historic sites were anticipated within the Project. 


\title{
This page has been removed intentionally to protect sensitive
}

\author{
cultural materials
}

Figure 3

Previousl surveys and documented archaeological sites within one kilometer of the project. 


\section{Chapter 3}

\section{Methodology}

The archeological survey conformed to survey standards set forth by the Council of Texas Archeologists (CTA) and included 100-percent visual inspection of the entirety of the proposed survey corridor. Additionally, the survey followed the West Texas Survey Methodologies, as required by the THC (2019).

Despite high surface visibility within the entire Project Area, shovel testing was carried out in 200-meter intervals to obtain a record of subsurface soil conditions and evaluate the potential for buried deposits. Where surface conditions and shovel test results suggested potential for buried cultural deposits, shovel tests were tightened to a 100 -meter interval.

Shovel tests measured 30 centimeters $(\mathrm{cm})$ in diameter and extended to a maximum depth of $80 \mathrm{~cm}$ below surface (cmbs), sterile subsoil, or bedrock; whichever was encountered first. Shovel tests were excavated in $20-\mathrm{cm}$ arbitrary levels and all soil was screened through $1 / 4$-inch hardware cloth. Shovel tests were digitally recorded using a GPS and ESRI Collector.

All Project notes, records, and photographs will be curated at the Center for Archaeological Studies (CAS) at Texas State University in San Marcos. No artifacts were collected during the survey. 


\section{Chapter 4}

\section{Survey Results}

Fieldwork took place on March 30 and 31, 2020 with Joel Butler serving as Principal Investigator and field director. Conditions were dry and temperatures were in the 70 s to 80 s during fieldwork with wind varying from near calm to 30 miles-per-hour with a passing dry line. A detailed depiction of the survey area with shovel test locations is provided in Figures 4-9 and shovel test results are presented in tabular form in Appendix A.

Vegetation observed around the Project Area consisted of clump grasses, miscellaneous desert forbs, mesquite, Spanish dagger, prickly pear, and creosote brush. The ground surface consisted of fine silty or sandy loams with exposed decayed caliche soil in the western portion of the APE.

\section{Disturbances in the APE}

The entire east-west portion of the Project is located parallel to and on the northern edge of a 200-foot wide existing pipeline corridor (Figures 4-8, Figure 10). The existing corridor had been cleared, trenched, and bladed flat.

In addition to the existing pipeline corridor, the eastern 9,300 feet of the Project (approximately 60 percent of the total length) had been heavily impacted by prior earthworks. Visible on aerial photographs as old as 1954, long circular terraces, one to two feet in height and spaced 60 to 70 feet apart, are seen over several square miles around the Project Area (Figures 11 and 12). It is suspected that this was done by using long ripping teeth on bulldozers to turn up soil and discourage runoff in the area, though the terraces do not conform to local topography. Regardless of the purpose, the result of these terraces are large caliche cobbles turned up from as deep as three to four feet. Toward the eastern end of the project, the circular furrows were replaced by hummocks of caliche cobbles on the surface. These hummocks were most likely from a more recent brush removal project, as few mesquite trees beyond saplings were visible in that area (Figure 12). 
Archeological Resource Survey of the Olifant Pipeline, Ward County, Texas.

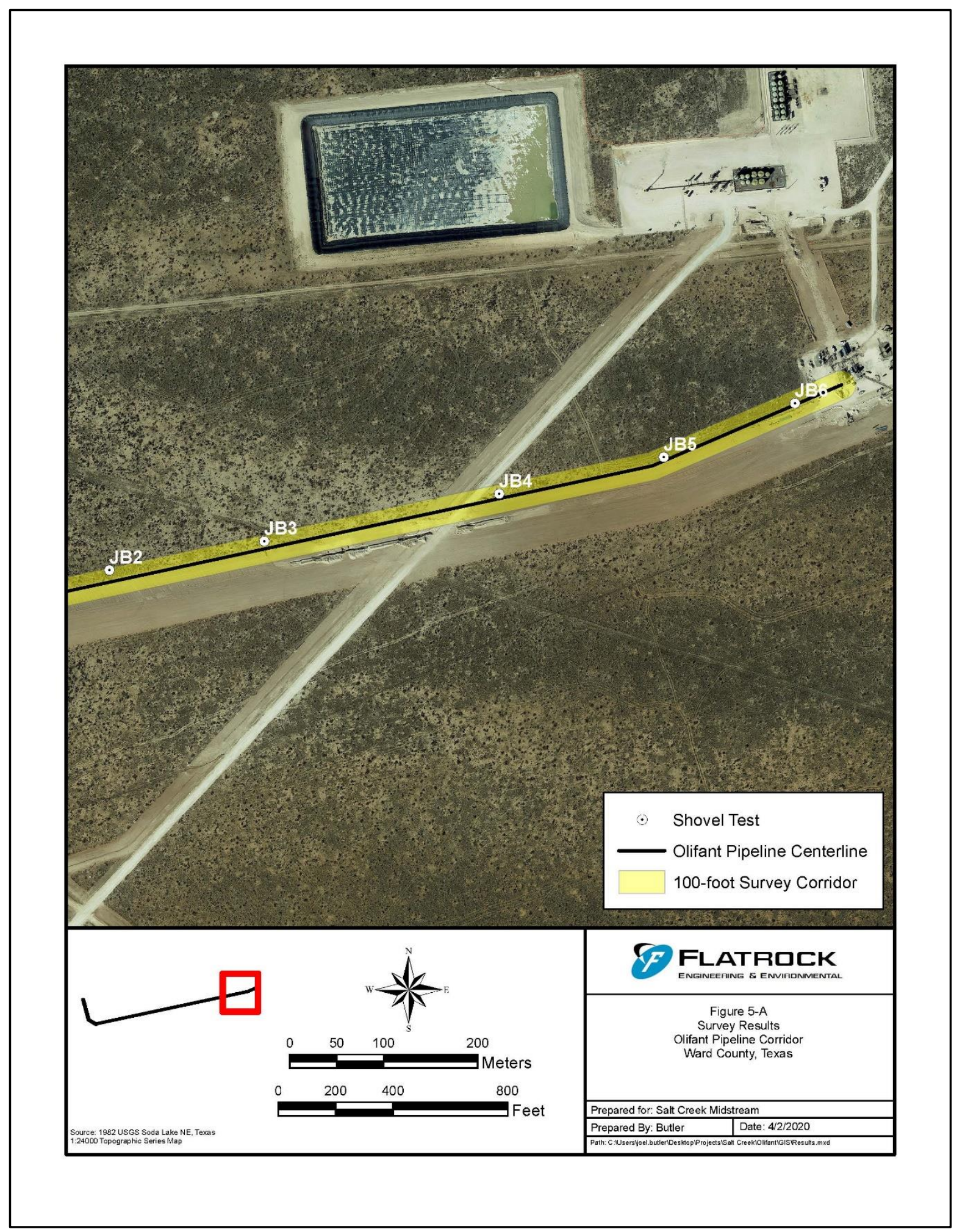

Figure 4. Survey results.

Flatrock Engineering \& Environmental, LLC 
Archeological Resource Survey of the Olifant Pipeline, Ward County, Texas.

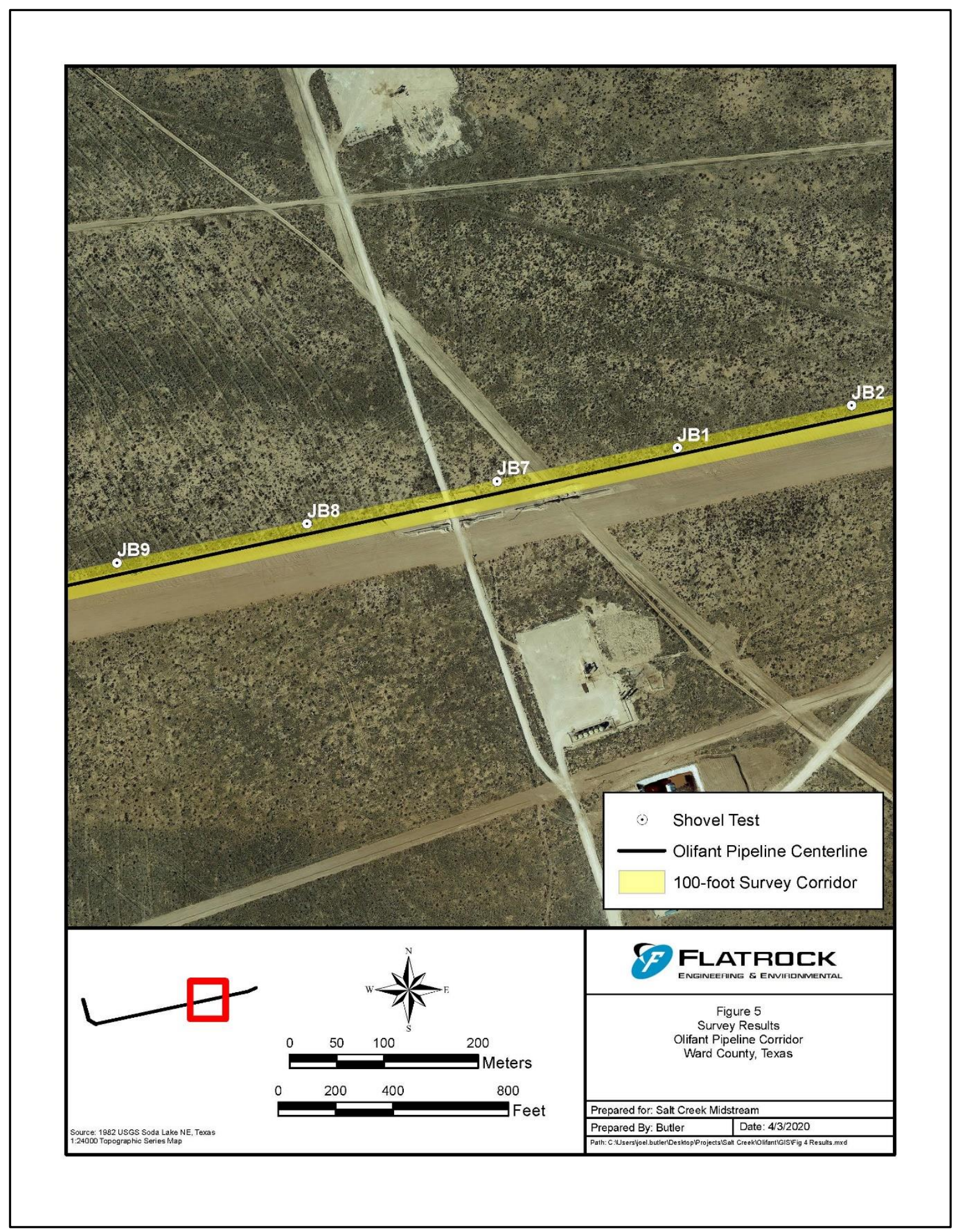

Figure 5. Survey results.

Flatrock Engineering \& Environmental, LLC 
Archeological Resource Survey of the Olifant Pipeline, Ward County, Texas.

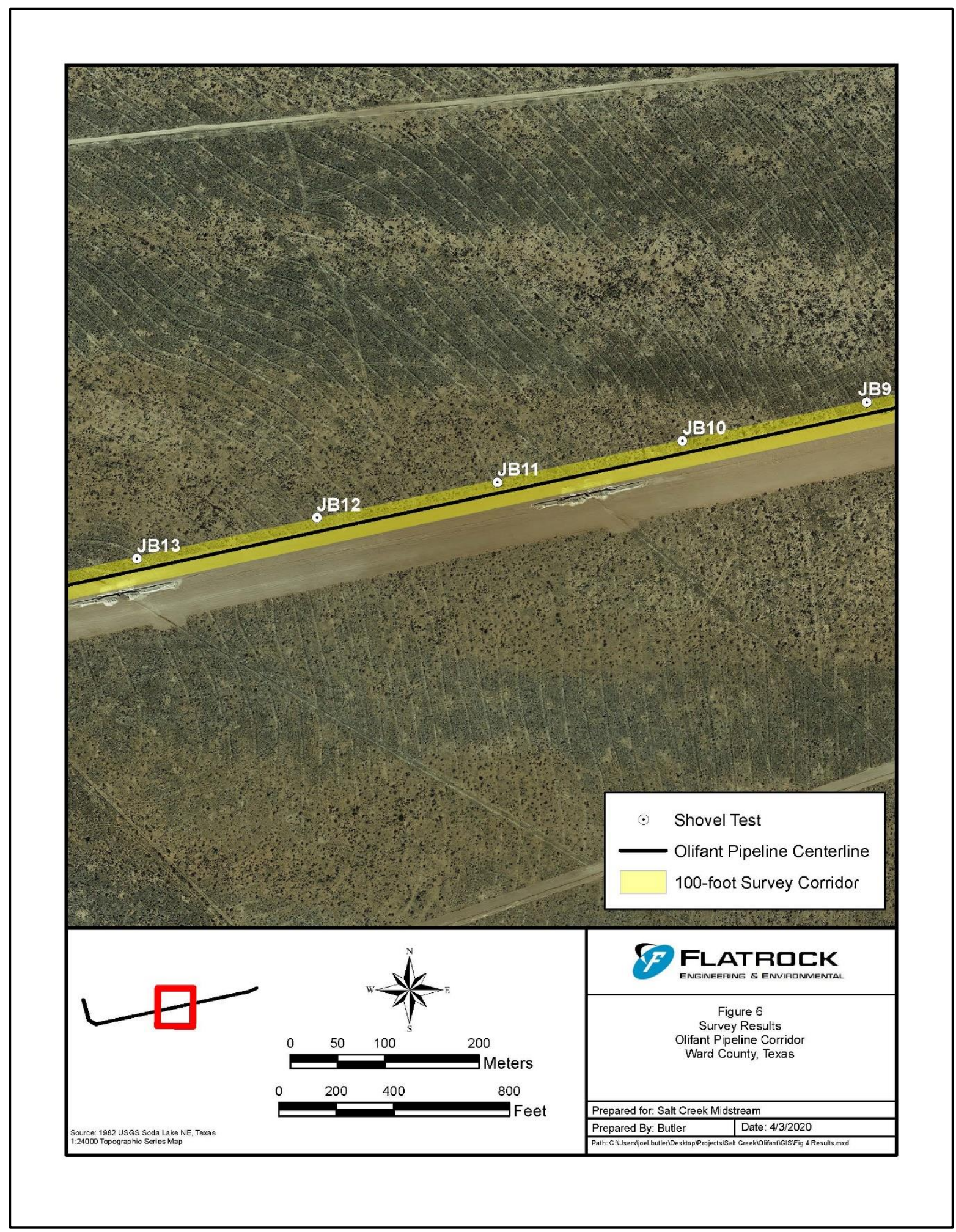

Figure 6. Survey results.

Flatrock Engineering \& Environmental, LLC 
Archeological Resource Survey of the Olifant Pipeline, Ward County, Texas.

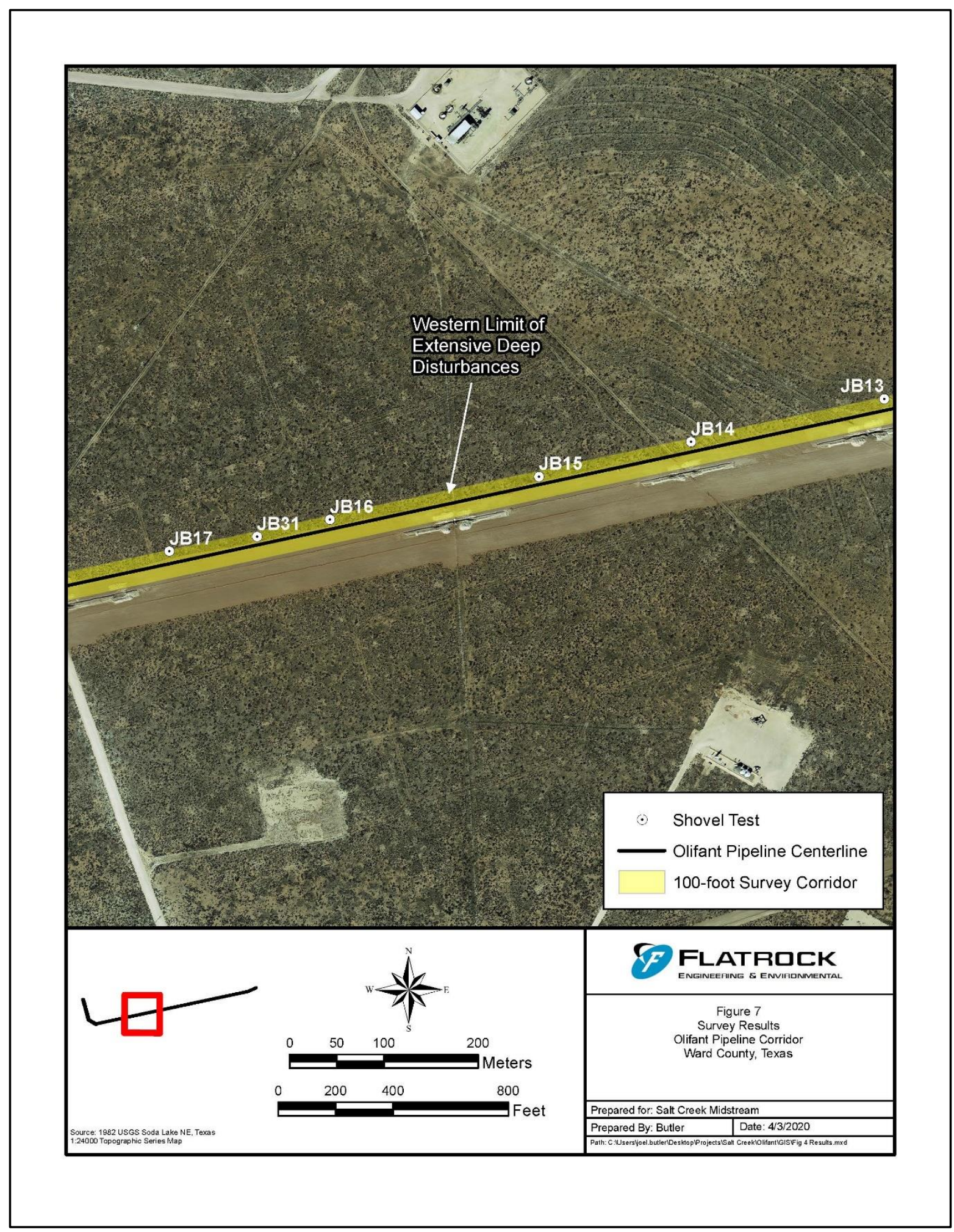

Figure 7. Survey results.

Flatrock Engineering \& Environmental, LLC 
Archeological Resource Survey of the Olifant Pipeline, Ward County, Texas.

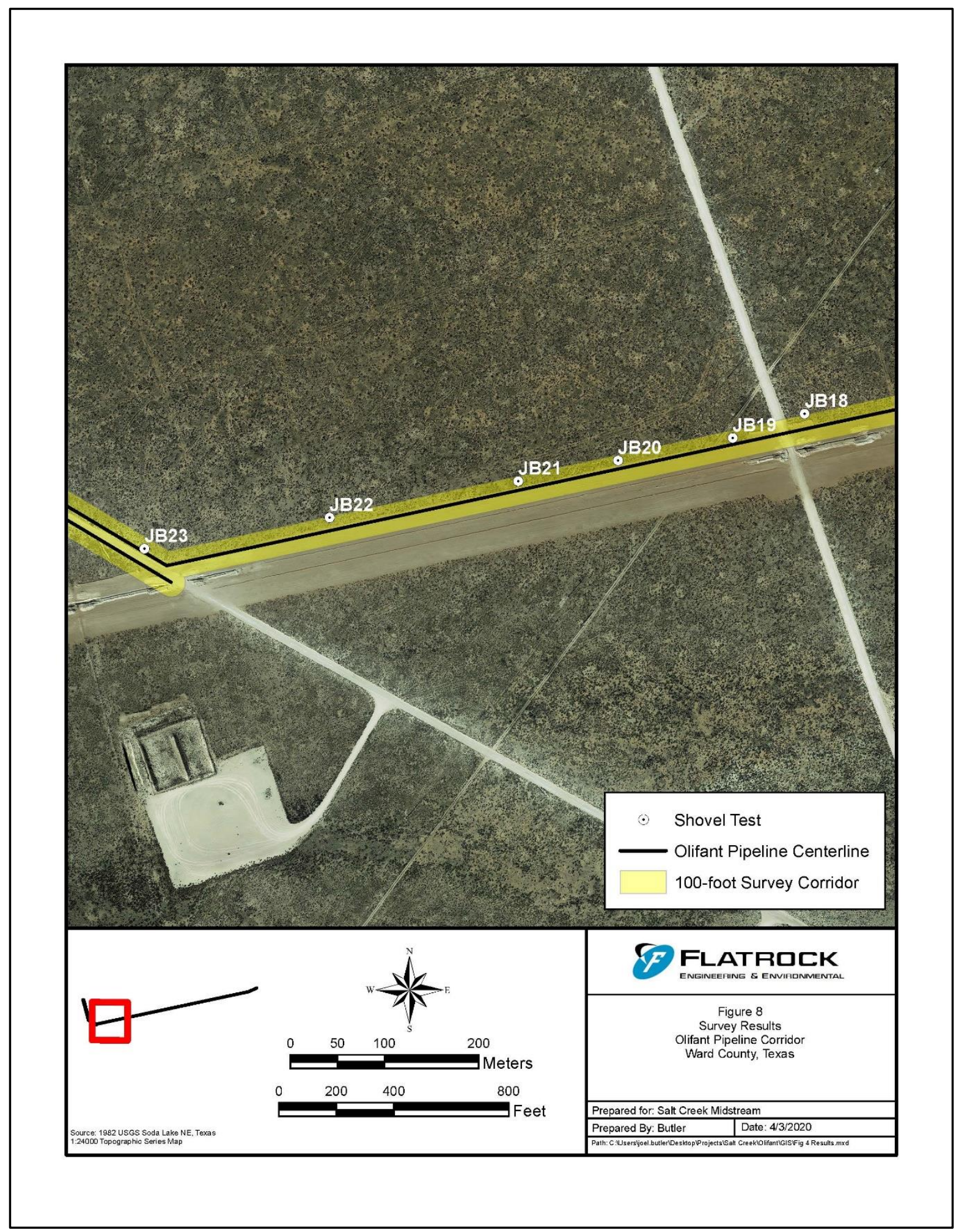

Figure 8. Survey results.

Flatrock Engineering \& Environmental, LLC 
Archeological Resource Survey of the Olifant Pipeline, Ward County, Texas.

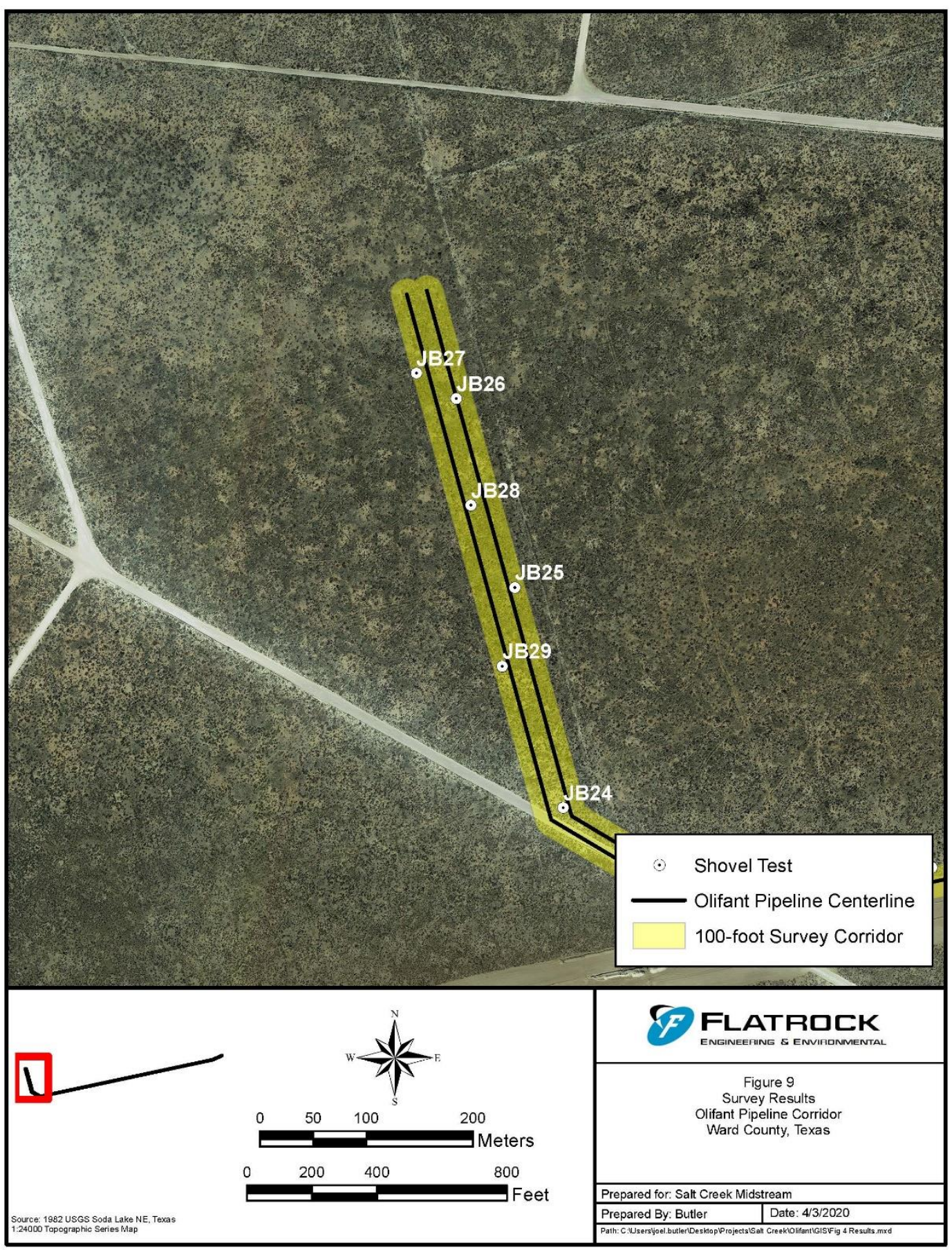

Figure 9. Survey results.

Flatrock Engineering \& Environmental, LLC 
Archeological Resource Survey of the Olifant Pipeline, Ward County, Texas.

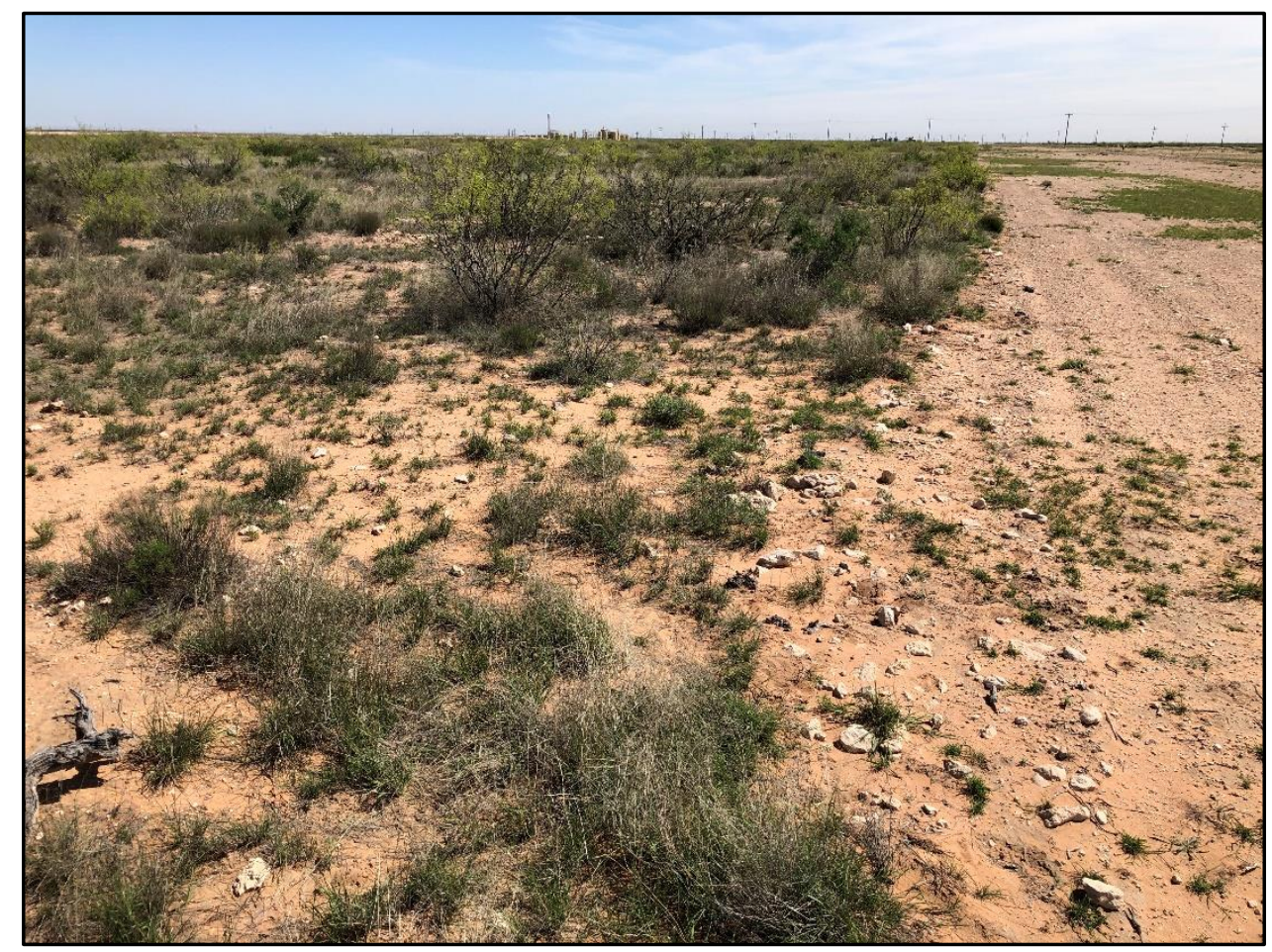

Figure 10. View of the Project centerline with existing pipeline ROW on right, facing east. 
Archeological Resource Survey of the Olifant Pipeline, Ward County, Texas.

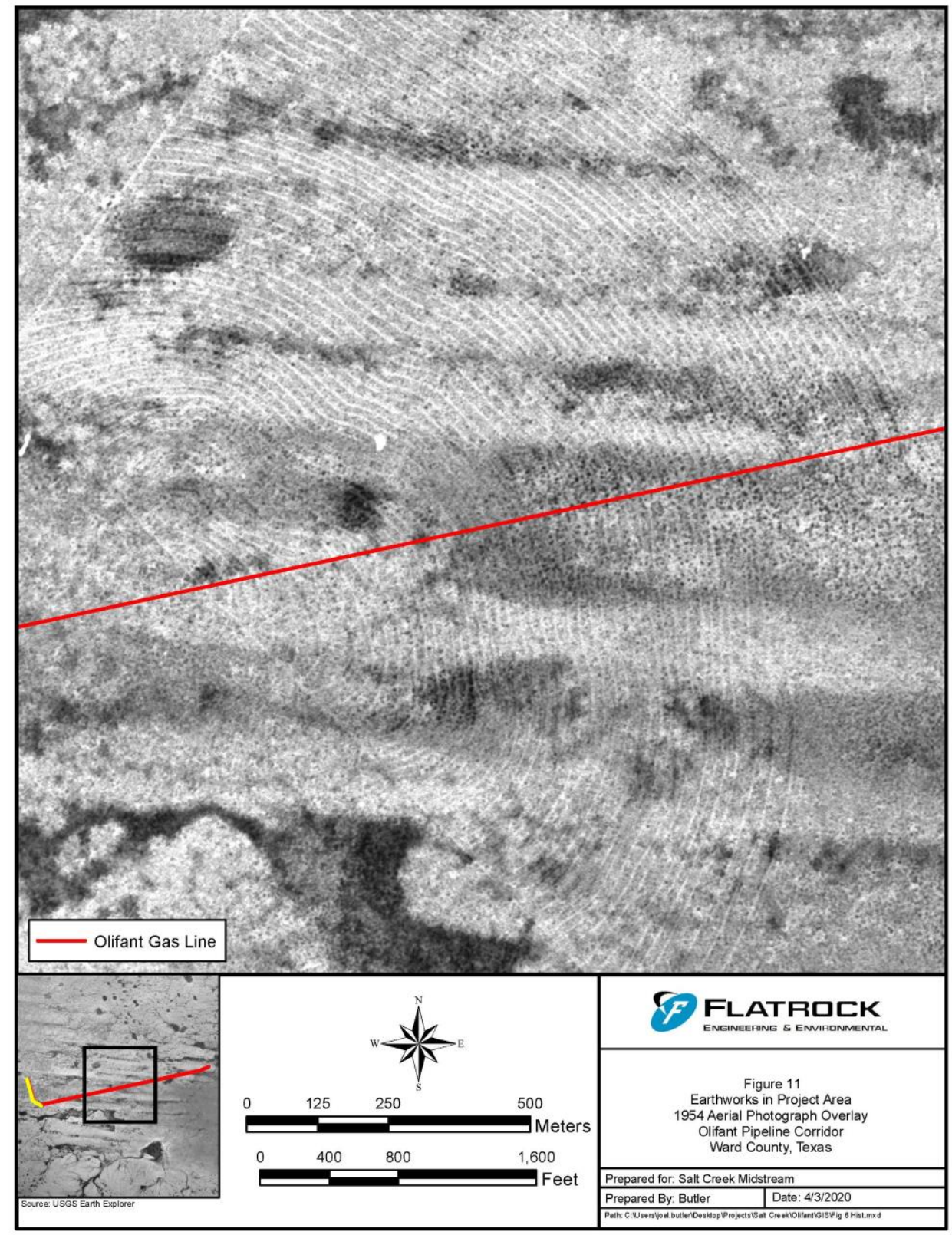

Figure 11. 1954 detailed aerial view of earthworks in the Project Area.

Flatrock Engineering \& Environmental, LLC 


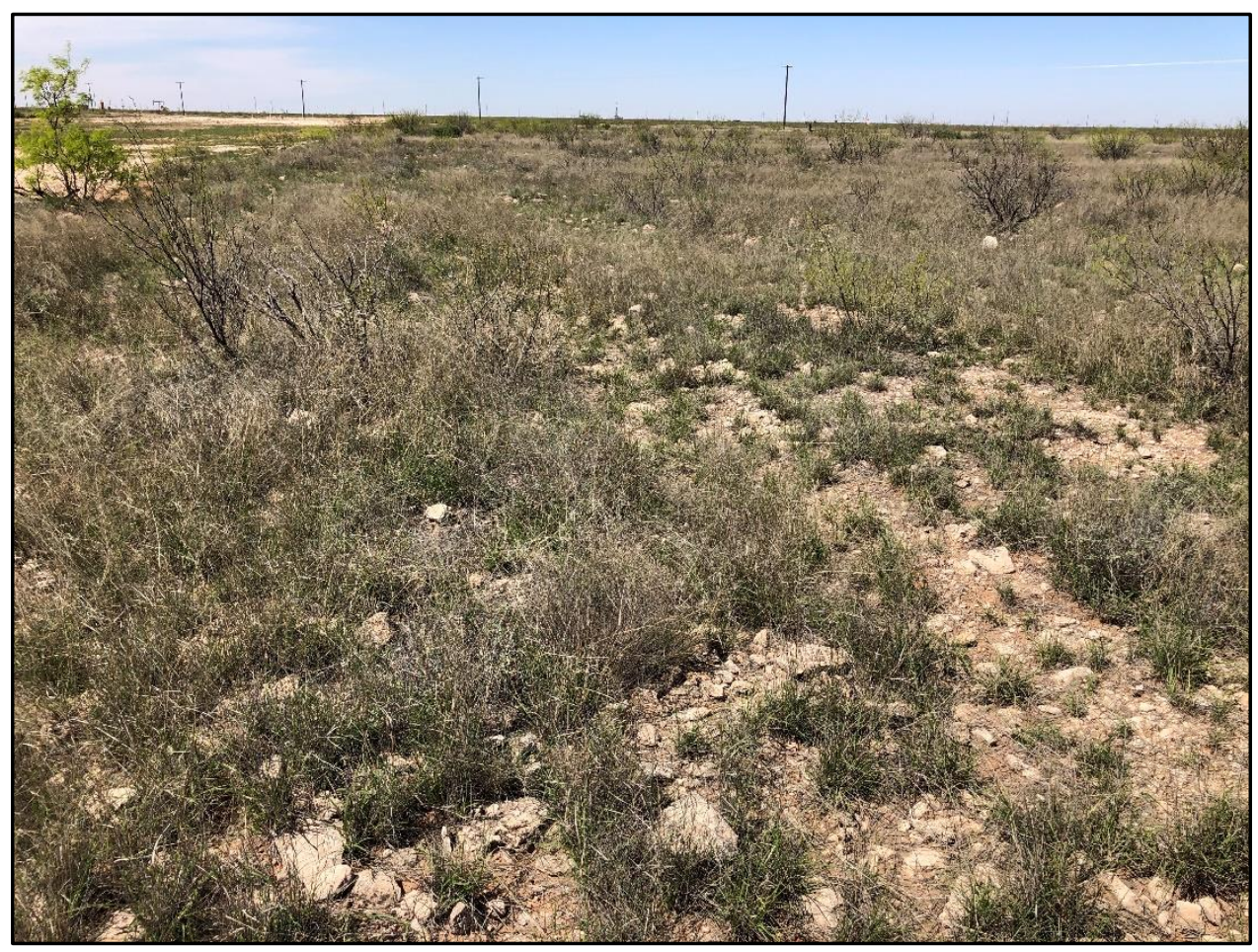

Figure 12. Ground view of earthworks in the eastern Project Area, note large quantities of caliche on the surface, facing west.

\section{Survey Results}

The entire survey corridor was examined during field survey by meandering within a 50 -foot transect on each side of the centerline. In addition to the less disturbed portions of the Project area, the existing pipeline corridor, hummocks, and linear terraces were inspected to identify any artifacts potentially uprooted during earth moving activities. Although the APE had greater than 80 percent surface visibility, no artifacts were identified as a result of visual inspection.

Shovel testing was carried out in 200-meter intervals throughout most of the Project Area. Tests varied in depth from near the surface to $60 \mathrm{cmbs}$. Shovel tests were all terminated where caliche or hardpan clay was encountered. Soils were, with few exceptions, silty sand or sandy loam, except in the far western portion of the Project, where sandy caliche soils were present near the surface, underlain at 10 to $15 \mathrm{cmbs}$ by large caliche cobbles.

Throughout the disturbed areas, shovel tests were placed between hummocks and terraces to evaluate disturbances, which seemed to be limited to the piled debris areas alone, with soils in between being apparently intact with few displaced caliche cobbles.

Approximately 400 meters west of the disturbed areas, a series of intact coppice dunes, one to two feet in height, were observed and potential for archeological sites or isolated artifacts was determined to be high. As a result, shovel tests JB16 to JB21 and JB31 were excavated in 100-meter intervals and the surface was closely inspected in that area (Figures 7 and 8 and Figure 13). Shovel tests in the vicinity of the dunes were mostly shallow and encountered large caliche cobbles near the surface with the exception of JB17, 
which contained sandy loam to a depth of $50 \mathrm{cmbs}$ before terminating at an apparent Bk horizon containing hardpan clay and caliche nodules.

No isolated artifacts or archeological sites were encountered during fieldwork.

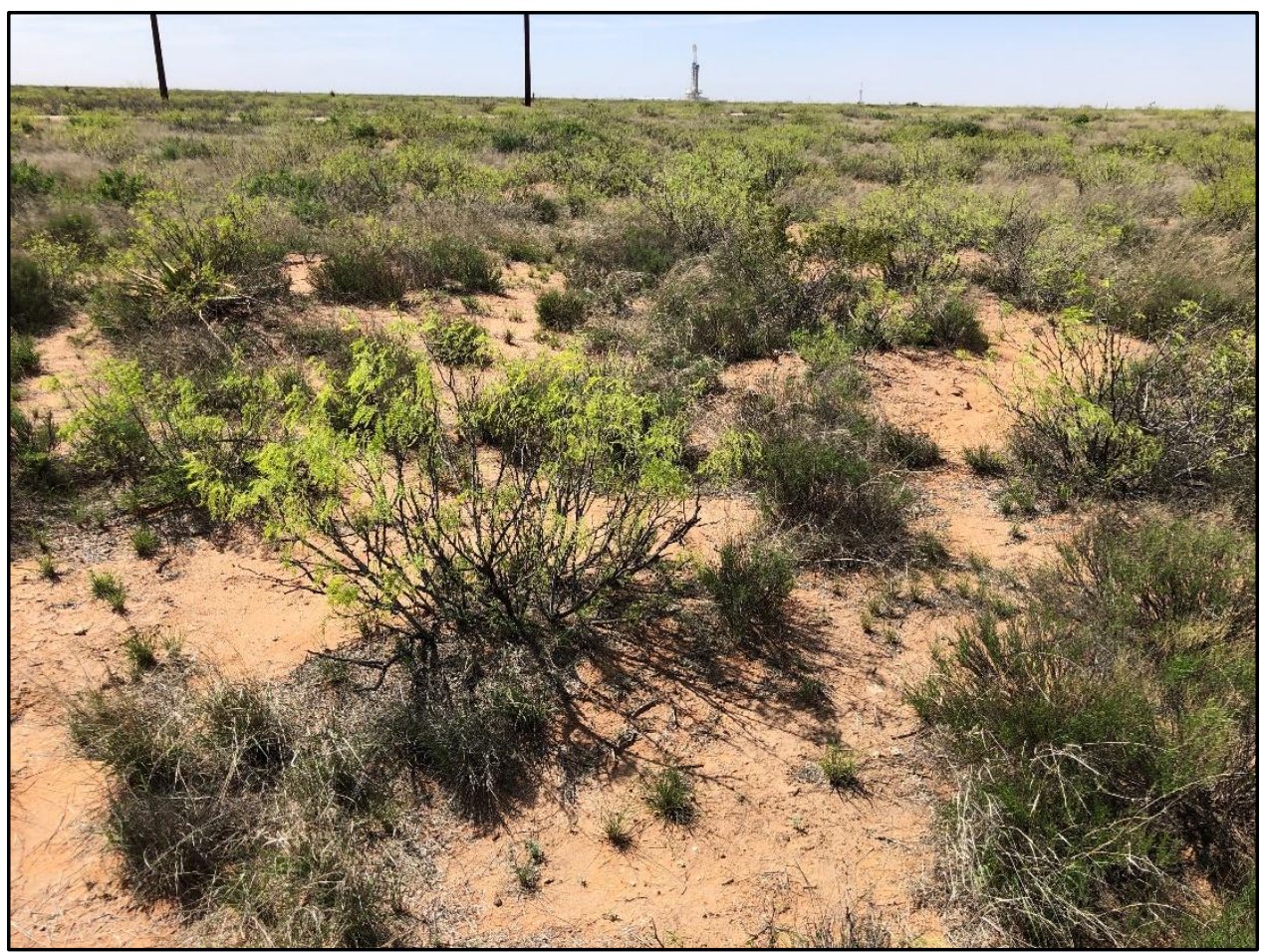

Figure 13. Intact coppice dunes in western portion of the Project Area, facing northwest. 


\section{Chapter 5}

\section{Summary and Recommendations}

On March 30 and 31, 2020, Flatrock archeologist Joel Butler carried out an intensive archeological survey of the entire 38.7-acre survey corridor along the proposed 2.9-mile (15,312 feet) Olifant pipeline, located on University Land in northern Ward County, Texas. Approximately 60 percent of the surveyed area had been disturbed by previous earthworks dating to at least the 1950s. Surface visibility varied from 80-100 percent within the APE. During the survey, 31 shovel tests were excavated to depths of $10-60 \mathrm{cmbs}$, all of which were negative. No standing historic structures were visible from the survey corridor. No isolated artifacts or archeological sites were discovered during fieldwork.

Flatrock recommends that no further work is necessary within the Project Area prior to construction. It is advised that if any cultural resources are encountered during Project construction, the THC and University Lands should be notified, and finds should be examined and evaluated by a qualified archeologist.

All work was carried out to conform with CTA guidelines as well as THC staff's recommended methods for archeological surveys in the West Texas region. Work was conducted under Texas Antiquities Permit number 9355. No artifacts were collected during this survey. All field records will be permanently housed at CAS in San Marcos. 


\section{References Cited}

Black, S. L.

1989 South Texas Plains. In From the Gulf of the Rio Grande: Human Adaptation in Central, South and Lower Pecos Texas, by T. R. Hester, S. L. Black, D. G. Steele, B. W. Olive, A. A. Fox, K. J. Reinhard, and L. C. Bement, pp. 39-62. Research Series No. 33. Arkansas Archaeological Survey, Fayetteville.

Bousman, C. B.

1998 Paleoenvironmental Change in Central Texas: The Palynological Evidence. Plains Anthropologist 43 (164):201-219

Bousman, C. B., S. A. Tomka, and G. L. Bailey

1990 Prehistoric Archaeology and paleoenvironments in Hidalgo and Willacy Counties, South Texas: Results of the Phase II Test Excavations. Reports of Investigations No. 76. Prewitt and Associates, Inc., Austin.

Collins, M. B.

1995 Forty Years of Archaeology in Central Texas. Bulletin of the Texas Archeological Society 66:361400.

Gault School

2019 "The Gault Site." http://www.gaultschool.org/, accessed November 2019.

Gilbert, M.T.P., D.L. Jenkins, A. Gotherstrom, N. Naveran, J.J. Sanchez, M. Hofreiter, P.F. Thomsen, J. Binladen, T.F.G. Higham, R.M. Yohe II, R. Parr, L.S. Cummings and E. Willerslev

2008 DNA from Pre-Clovis Human Coprolites in Oregon, North America. Science 320: 786-789.

Hester, T. R.

1980 Digging Into South Texas Prehistory: A Guide for the Amateur Archaeologist. Corona Publishing Company San Antonio, Texas.

1995 The Prehistory of South Texas. Bulletin of the Texas Archaeological Society 66:427-459.

Mauldin, R. P., and D. L. Nickels

2001 An Archaeological Survey of Twin Buttes Reservoir, Tom Green County, Texas. Archaeological Survey Report No. 300. Center for Archaeological Research, The University of Texas at San Antonio.

Miller, M. R. and N. A. Kenmotsu

2004 Prehistory of the Jornada Mogollon and Eastern Trans-Pecos Regions of West Texas. In The Prehistory of Texas, edited by T.K. Perttula, pp. 205-265. Texas A\&M University Press, College Station.

Omernik, G. E., and J. M. Griffith

2009 Ecoregions of Texas (EPA) - The Encyclopedia of Earth. Electronic document, http://editors.eol.org/ eoearth/wiki/Main_Article:_Ecoregions_of_Texas_(EPA), accessed November 2019. 
Perttula, T. K. (Editor)

2004 The Prehistory of Texas. Texas A\&M Press, College Station.

Pitblado, B.L.

2011A Tale of Two Migrations: Reconciling Recent Biological and Archaeological Evidence for the Pleistocene Peopling of the Americas. Journal of Archaeological Research 19(4): 327-375.

Stahl, C., and R. McElvaney

2012 Trees of Texas: An Easy Guide to Leaf Identification. Texas A\&M University Press, College Station.

Swaminathan, N.

2014 Debra L. Friedkin Site. American Archaeology Magazine Online. http://www.archaeology.org/ issues/145-1409/features/2371-peopling-the-americas-friedkin-site, accessed November 2019.

Texas Historical Commission Historic Sites Atlas (THC)

2020Texas Archeological Sites Atlas online. Texas Historical Commission. Electronic document, http://nueces.thc.state.tx.us/, accessed April 2020.

Toomey, R. S., M. D. Blum, and S. Valastro, Jr.

1993 Late Quaternary Climates and Environments of the Edwards Plateau, Texas. Global and Planetary Change 7:299-320.

Turpin, Solveig A.

1995 The Lower Pecos River Region of Texas and Northern Mexico. Bulletin of the Texas Archaeological Society 66: 541-560.

United States Department of Agriculture, Natural Resources Conservation Service (USDA-NRCS)

2020 Web Soil Survey, Newton and Orange Counties Texas. Electronic document, http://websoilsurvey. nrcs.usda.gov/app/WebSoilSurvey.asp, accessed April 2020.

United States Geological Survey (USGS)

2007 Geologic Database of Texas. Vector digital GIS data. Austin.

University of Missouri

2020 "Ag Site Assessment Tool." https://agsite.missouri.edu/ag-site-assessment/, accessed April 2020. 
Archeological Resource Survey of the Olifant Pipeline, Ward County, Texas.

\section{Appendix: Shovel Test Results}




\begin{tabular}{|c|c|c|c|c|c|c|}
\hline $\begin{array}{c}\text { Shovel } \\
\text { Test }\end{array}$ & $\begin{array}{l}\text { 0-20 cmbs } \\
\text { Soil Type }\end{array}$ & $\begin{array}{c}0-20 \\
\text { cmbs Soil } \\
\text { Color }\end{array}$ & $\begin{array}{c}20-40 \mathrm{cmbs} \\
\text { Soil Type }\end{array}$ & $\begin{array}{c}20-40 \\
\text { cmbs Soil } \\
\text { Color }\end{array}$ & $\begin{array}{l}\text { 40-60 cmbs } \\
\text { Soil Type }\end{array}$ & $\begin{array}{c}40-60 \\
\text { cmbs Soil } \\
\text { Color }\end{array}$ \\
\hline JB1 & $\begin{array}{l}\text { Silty loam } \\
\text { with small } \\
\text { caliche } \\
\text { pebbles }\end{array}$ & 10YR 4/6 & $\begin{array}{l}\text { Silty loam } \\
\text { with large } \\
\text { dense } \\
\text { caliche. } \\
\text { Compact at } \\
40 \\
\end{array}$ & 10YR 4/4 & & \\
\hline JB2 & Silty sand & 10YR 4/6 & $\begin{array}{l}\text { Silty sand } \\
\text { with very } \\
\text { large dense } \\
\text { caliche }\end{array}$ & 10YR 4/4 & & \\
\hline JB3 & Silty Sand & 10YR 4/2 & Silty Sand & 10YR 4/2 & $\begin{array}{l}\text { Silty sand to } \\
\text { compact hard } \\
\text { pan and } \\
\text { caliche at } 50\end{array}$ & \\
\hline JB4 & Silty loam & 10YR 4/6 & $\begin{array}{l}\text { Silty loam to } \\
\text { hard pan with } \\
\text { caliche }\end{array}$ & 10YR 4/4 & & \\
\hline JB5 & $\begin{array}{l}\text { Silty sand } \\
\text { with caliche } \\
\text { cobbles at } \\
10\end{array}$ & 10YR 4/6 & & & & \\
\hline JB6 & Silty sand & 10YR 4/6 & $\begin{array}{l}\text { Silty sand to } \\
\text { caliche } \\
\text { pebbles at } 40\end{array}$ & 10YR 4/6 & & \\
\hline JB7 & Silty sand & 10YR 4/6 & $\begin{array}{l}\text { Silty sand to } \\
\text { hardpan at } 35\end{array}$ & 10YR 4/4 & & \\
\hline JB8 & $\begin{array}{l}\text { Sandy loam } \\
\text { to dense } \\
\text { caliche }\end{array}$ & 10YR 4/6 & & & & \\
\hline JB9 & $\begin{array}{l}\text { Sandy loam } \\
\text { with dense } \\
\text { caliche } \\
\text { gravels near } \\
\text { surface }\end{array}$ & & & & & \\
\hline JB10 & Sandy loam & 10YR 4/6 & $\begin{array}{l}\text { Sandy loam } \\
\text { to hard pan at } \\
40\end{array}$ & 10YR 4/6 & & \\
\hline JB11 & Sandy loam & 10YR 4/6 & $\begin{array}{l}\text { Sandy loam } \\
\text { to hard pan at } \\
40\end{array}$ & 10YR 4/6 & & \\
\hline JB12 & Sandy loam & 10YR 4/6 & $\begin{array}{l}\text { Sandy loam } \\
\text { to hard pan at } \\
40\end{array}$ & 10YR 4/6 & & \\
\hline JB13 & Sandy loam & 10YR 4/6 & Sandy loam & 10YR 4/6 & $\begin{array}{l}\text { Sandy loam } \\
\text { to hardpan } \\
\text { caliche at } 50\end{array}$ & 10YR 4/4 \\
\hline JB14 & $\begin{array}{l}\text { Sandy loam } \\
\text { caliche } \\
\text { pebbles } \\
\text { throughout }\end{array}$ & 10YR 4/6 & & & & \\
\hline
\end{tabular}

Flatrock Engineering \& Environmental, LLC 
Archeological Resource Survey of the Olifant Pipeline, Ward County, Texas.

\begin{tabular}{|c|c|c|c|c|c|c|}
\hline $\begin{array}{c}\text { Shovel } \\
\text { Test }\end{array}$ & $\begin{array}{l}0-20 \mathrm{cmbs} \\
\text { Soil Type }\end{array}$ & $\begin{array}{c}0-20 \\
\text { cmbs Soil } \\
\text { Color }\end{array}$ & $\begin{array}{c}20-40 \mathrm{cmbs} \\
\text { Soil Type }\end{array}$ & $\begin{array}{c}20-40 \\
\text { cmbs Soil } \\
\text { Color }\end{array}$ & $\begin{array}{c}\text { 40-60 cmbs } \\
\text { Soil Type }\end{array}$ & $\begin{array}{c}40-60 \\
\text { cmbs Soil } \\
\text { Color }\end{array}$ \\
\hline JB15 & $\begin{array}{l}\text { Sandy loam } \\
\text { with dense } \\
\text { caliche near } \\
\text { surface }\end{array}$ & 10YR 4/6 & & & & \\
\hline JB16 & $\begin{array}{l}\text { Sandy loam } \\
\text { with dense } \\
\text { caliche } \\
\text { nodules at } \\
20\end{array}$ & 10YR 4/6 & & & & \\
\hline JB17 & Sandy loam & 10YR 4/6 & Sandy loam & 10YR 4/6 & $\begin{array}{l}\text { Sandy loam } \\
\text { with large } \\
\text { caliche } \\
\text { nodules at } 50\end{array}$ & \\
\hline JB18 & $\begin{array}{l}\text { Sandy loam } \\
\text { with dense } \\
\text { caliche near } \\
\text { surface }\end{array}$ & 10YR 4/6 & & & & \\
\hline JB19 & $\begin{array}{l}\text { Sandy loam } \\
\text { with dense } \\
\text { caliche near } \\
\text { surface }\end{array}$ & 10YR 4/6 & & & & \\
\hline JB20 & $\begin{array}{l}\text { Sandy loam } \\
\text { with dense } \\
\text { caliche near } \\
\text { surface }\end{array}$ & 10YR 4/6 & & & & \\
\hline JB21 & $\begin{array}{l}\text { Sandy loam } \\
\text { with dense } \\
\text { caliche near } \\
\text { surface }\end{array}$ & 10YR 4/6 & & & & \\
\hline JB22 & $\begin{array}{l}\text { Sandy loam } \\
\text { with dense } \\
\text { caliche near } \\
\text { surface }\end{array}$ & 10YR 4/6 & & & & \\
\hline JB23 & $\begin{array}{l}\text { Sandy } \\
\text { caliche }\end{array}$ & 10YR 6/4 & & & & \\
\hline JB24 & $\begin{array}{l}\text { Sandy } \\
\text { caliche }\end{array}$ & 10YR 6/4 & & & & \\
\hline JB25 & $\begin{array}{l}\text { Sandy loam } \\
\text { with caliche } \\
\text { pebbles } \\
\text { increasing }\end{array}$ & 10YR 4/6 & & & & \\
\hline JB26 & $\begin{array}{l}\text { Sandy } \\
\text { caliche }\end{array}$ & 10YR 6/4 & & & & \\
\hline JB27 & $\begin{array}{l}\text { Sandy } \\
\text { caliche }\end{array}$ & 10YR 6/4 & & & & \\
\hline JB28 & $\begin{array}{l}\text { Sandy } \\
\text { caliche }\end{array}$ & 10YR 6/4 & & & & \\
\hline
\end{tabular}

Flatrock Engineering \& Environmental, LLC 
Archeological Resource Survey of the Olifant Pipeline, Ward County, Texas.

\begin{tabular}{|c|c|c|c|c|c|c|}
\hline $\begin{array}{c}\text { Shovel } \\
\text { Test }\end{array}$ & $\begin{array}{l}0-20 \text { cmbs } \\
\text { Soil Type }\end{array}$ & $\begin{array}{c}0-20 \\
\text { cmbs Soil } \\
\text { Color }\end{array}$ & $\begin{array}{c}20-40 \mathrm{cmbs} \\
\text { Soil Type }\end{array}$ & $\begin{array}{c}20-40 \\
\text { cmbs Soil } \\
\text { Color }\end{array}$ & $\begin{array}{c}40-60 \mathrm{cmbs} \\
\text { Soil Type }\end{array}$ & $\begin{array}{c}40-60 \\
\text { cmbs Soil } \\
\text { Color }\end{array}$ \\
\hline JB29 & $\begin{array}{l}\text { Sandy loam } \\
\text { with caliche } \\
\text { near surface }\end{array}$ & 10YR 4/6 & & & & \\
\hline JB30 & $\begin{array}{l}\text { Sandy } \\
\text { caliche }\end{array}$ & 10YR 6/4 & & & & \\
\hline JB31 & $\begin{array}{l}\text { Sandy loam } \\
\text { with caliche } \\
\text { near surface }\end{array}$ & 10YR 4/6 & & & & \\
\hline
\end{tabular}

